\title{
The Nonlinear Effect of Infill Walls Stiffness to Prevent Soft Story Col- lapse of RC Structures
}

\author{
D. Guney*,1 and E. Aydin ${ }^{2}$
}

\author{
${ }^{1}$ Yildiz Technical University, Faculty of Architecture, Structural System Division, 34349, Istanbul, Turkey; ${ }^{2}$ Nigde Uni- \\ versity, Faculty of Engineering, Civil Eng. Department, 51245, Nigde, Turkey
}

\begin{abstract}
Experimental or theoretical tests show that dramatically changes of infill area causes soft story mechanism. "Soft story" mechanism is the most frequent failure mode of reinforced concrete (R.C.) structures. This phenomenon is caused by the fact that the overall shear force applied to the building by an earthquake is higher at the base floor. If the lower story is not originally weakened, it is however there that infill are the most stressed, so that they fail first and create the weak story and finally leads collapse of structures. This kind of collapse was observed many times in Turkey caused by earthquake. The aim of this paper is to show the contribution of infill walls to the building response during earthquake. Different type of configuration of infill walls are modeled and analyzed by the Finite Element Method. These models also have soft story risk. The nonlinear force-displacement behavior is used for structural analysis. El Centro N-S component is used for time-history analysis.
\end{abstract}

Keywords: Infill walls, soft story, seismic response, finite element method, earthquake.

The Scope of the Special Issue Includes: Modeling of seismic response of infilled frame structures.

\section{INTRODUCTION}

The most frequent failure mode of reinforced concrete frame buildings caused by earthquake is called "soft storey" mechanism. It consists in a localization of buildings' seismic deformations and rupture in the bottom story of the building (Fig. 1). This phenomenon is caused by the fact that the overall shear force applied to the building by an earthquake is higher at the base due to the following factors:

- wide openings are present in the bottom story and not present at upper levels and weaken the structure - ground level is often used for offices, shops, lobby in hotels, etc.

- Columns are at ground level are too slender.

- If the lower story is weakened, it is however there those infills are the most stressed, so that they fail first and create the weak story.

In many applications, architectural considerations result in a taller first story, which causes a soft-story formation due to sudden change in the vertical stiffness between following stories. The presence of a soft story results in a localized excessive drift that causes heavy damage or collapse of the story during a severe earthquake. Another typical case of soft story arises when the first floor is left open to serve a commercial function (stores) or as a parking garage (very common in Turkey), while upper floors are infilled with unreinforced masonry walls. A relatively rare case results when the strength of the two adjacent stories is significantly different (weak story) leading to localized deformations similar to the soft-story mechanism. In this paper, the second reason has been analyzed.

*Address correspondence to this author at the Yildiz Technical University Faculty of Architecture Structural System Division Yildiz Besiktas 34349 Istanbul Turkey; Tel: +90 212 3832615; Fax: + 90212 3832660;

E-mails: deguney@yildiz.edu.tr; dguney@gmail.com
Existence of infill walls in the frame is very important not only to prevent soft story mechanism but also lateral rigidity of the frame. The behavior of empty frames and infilled frames is very different. The contribution of masonry infills to the global capacity of the structure constitutes the structural strength to the $80 \%$ and stiffness to the $85 \%$. The main reason of their beneficial behavior is that the amount of increase in earthquake inertia force appears to be relatively small, comparatively with the increase in the strength of masonry infills [1].

Widely used masonry infill elements in the reinforced concrete frame building design are adobe blocks, hallow bricks, solid bricks, clay bricks, aerated concrete blocks, briquette blocks etc. Although there is no general acceptance of the contribution of infill walls in the earthquake resistant design many researches point out that negative effects are often associated with irregularities in the distribution of infills in plan and/or in the evaluation. The main problem in the design process is mostly that masonry infills have asbuilt properties and it is almost impossible to take into account reliably [2]. Due to the design and methodological complexity incorporation of infill walls in the numerical analysis as structural elements is not common. Nevertheless, infill walls increase lateral stiffness and minimize P- $\Delta$ effect [3]. The main problem of analyzing the infill frame reinforced concrete buildings is that mostly it is impossible to estimate reliably as built properties in the design procedure. Standardization of masonry units and mortar is not enough for characterization of the inelastic cyclic behavior of masonry infills [4]. A simple modification of the diagonal strut model is proposed in order to include some coupling between the two bars. The coupling is done by the introduction of a concept that the authors have called "plastic concentrator". A plastic concentrator can be compared with a plastic hinge in the sense that both may be imagined as zero length 

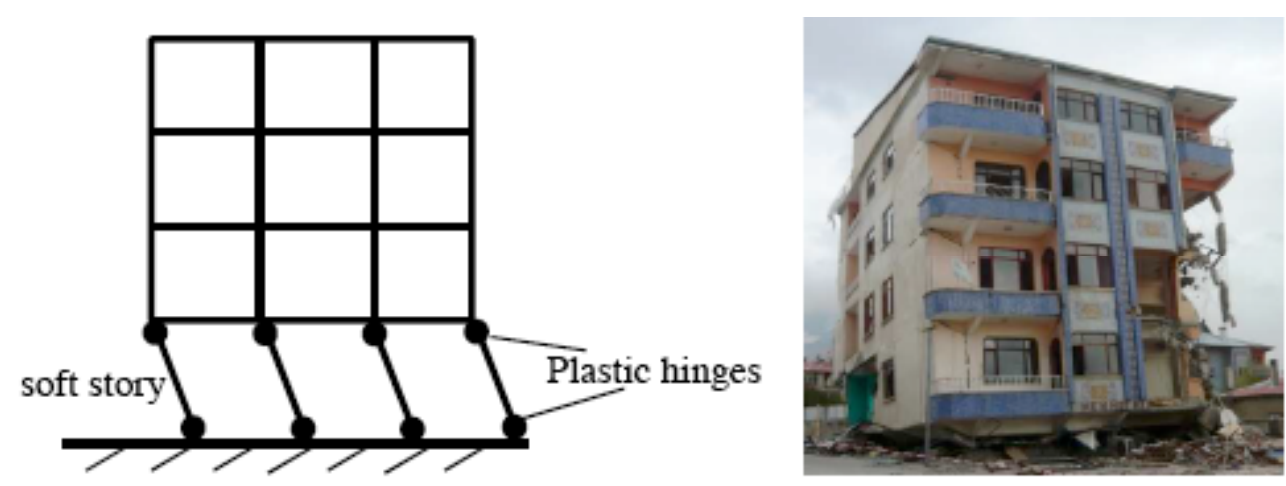

Fig. (1). The soft storey mechanism and collapsed building example

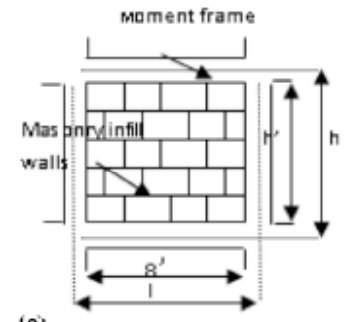

(a)

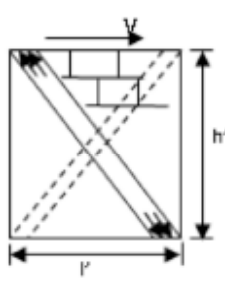

(b)

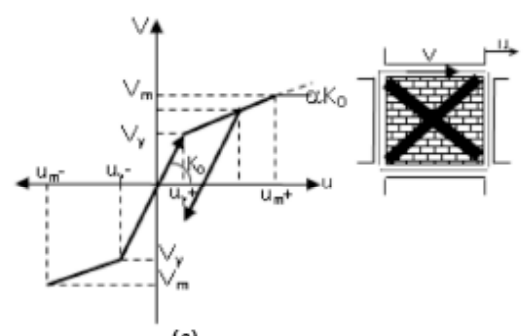

(c)

Fig. (2). Equivalent Strut Model for Masonry Infill Walls in Frame Structures: (a) Masonry Infill Frame Geometry, (b) Masonry Infill Walls and Strut [16] (c) Strength Envelope for Infill Walls.

inelastic springs [5, 6]. Another concept is the Applied Element Method (AEM) can track the structural collapse behavior during early stages of loading and can account for nonlinear behavior of structures including element separation [7]. A comprehensive overview of the analytical modelling techniques of infilled frame structures was prepared by Moghaddam and Dowling [8] and more recently by Crisafulli, et al., [9]. The most commonly used technique to model infill panels is that of single or multiple compressive equivalent diagonal struts [10]. Plumier et. all. investigated soft story mechanism of RC frames using by steel profiles in the columns of the lower levels the structure both theoretical and experimentally [11].

The experimental results indicate that the failure modes of the infilled frames can be classified into distinct modes. Such a classification of the failure modes (crack patterns) enhances considerably the understanding of the earthquake resistant behavior of infilled frames and leads to improved comprehension of their modeling, analysis and design [12]. The infill walls in multistory buildings have a considerable contribution to the stiffness and lateral resistance of frame. In particular, the case of infilled frame with infill walls in all three stories contributes to up to a $77 \%$ decrease of the lateral displacements [13]. The knowledge of the elastic response of composite structure will be very critical for a thorough understanding of its response under reversed cyclic loading $[14,15]$.

Soft story collapse was observed many times in Turkey caused by earthquake. The most important reason for soft story is irregular distribution of infill walls. Especially many buildings close to main road were renovated to get show- room. In order to do this transform in building function, many infill walls at ground floor were demolished. Many of those structures either collapsed or heavily damaged during the earthquake in 1999. The aim of this paper is to show the importance of infill walls to the building response during earthquake. Different type of configuration of infill walls are modeled and analyzed by the Finite Element Method using by real earthquake acceleration record. The behavior of infill walls are assumed as nonlinear.

\section{THE THEORETICAL MODEL}

The behavior of infill walls is assumed as bilinear forcedisplacement model as shown in Fig. (2). The equivalent strut model for masonry infill walls in frame structures is used. The size of strut is related with stiffness and geometry of the infill.

The maximum lateral force $\mathrm{Vm}$ and corresponding displacement um in the infill panel are shown in Eqs. 1 and 2. In the equation, $t$ is thickness of the infill wall, 1 ' is lateral dimension of the infill panel, $\mathrm{f}^{\prime} \mathrm{m}$ is masonry prism strength, $\varepsilon_{\mathrm{m}}$ is corresponding strain, $\theta$ is inclination of the diagonal strut, $\mathrm{V}$ is basic shear strength of masonry and $\mathrm{A}_{\mathrm{d}}$ and $\mathrm{l}_{\mathrm{d}}$ are area and length of the equivalent diagonal strut respectively.

$$
\begin{aligned}
& V^{+}{ }_{m}\left(V^{-}{ }_{m}\right) \leq A_{d} \cdot f_{m}^{\prime} \cdot \cos \theta \leq \frac{V \cdot t \cdot l^{\prime}}{\left(1-0.45 \tan \theta^{\prime}\right) \cos \theta} \leq \frac{0.83 \cdot t \cdot l^{\prime}}{\cos \theta} \\
& u^{+}{ }_{m}\left(u_{m}^{-}\right)=\frac{\varepsilon_{m}^{\prime} \cdot l_{d}}{\cos \theta}
\end{aligned}
$$

The monotonic lateral force-displacement curve is completely defined by the maximum force $\mathrm{V}_{\mathrm{m}}$, corresponding 
displacement $u_{m}$, the initial stiffness $K_{0}$ and the ratio $\alpha$ of the post-yield to initial stiffness. The initial stiffness $\mathrm{K}_{0}$ of the infill masonry wall may be estimated from the Eq. (3). The lateral yield force $\mathrm{V}_{\mathrm{y}}$ and displacement $\mathrm{u}_{\mathrm{y}}$ of the infill wall may be calculated from geometry Eq. (4). For practical purposes, the elastictiy modulus of the infill wall can be taken as 500-700 $\mathrm{f}_{\text {ckd }}$. $\mathrm{f}_{\text {ckd }}$ is characteristic shear strength which is taken about $2000-4000 \mathrm{kN} / \mathrm{m}^{2}$.

$$
\begin{aligned}
& K_{o}=\frac{E d \cdot A d}{l^{\prime}} \\
& V_{y}^{+}\left(V_{y}^{-}\right)=\frac{V_{m}-\alpha K_{o} u_{m}}{(1-\alpha)}, u_{y}^{+}\left(u_{y}^{-}\right)=\frac{V_{m}-\alpha K_{o} u_{m}}{K_{o}(1-\alpha)}
\end{aligned}
$$

Using these degrees of freedom, the dynamic response of the system to earthquake acceleration record $a_{g}(t)$ in the $x$ and $y$ direction, $\mathrm{a}_{\mathrm{g} \theta}(\mathrm{t})$ in the $\mathrm{z}$-direction and are described by the following equation of motion in Eq. $(5,6)$.

$$
M \ddot{u}(t)+C \dot{u}(t)+K u(t)=F_{e}(t)
$$

Eq. (7) shows lateral stiffness in $\mathrm{x}$ - and $\mathrm{y}$-directions. Eq. (8) represents the lateral torsional coupling in the system. Eq. (9) gives torsional stiffness of the system.

$$
\begin{aligned}
& C=\alpha M+\beta K \\
& \alpha=\xi \frac{\omega_{i} \omega_{j}}{\omega_{i}+\omega_{j}} \\
& \beta=\xi \frac{2}{\omega_{i}+\omega_{j}}
\end{aligned}
$$

In this paper, proportional damping is considered where the damping matrix is a combination of the mass and stiffness matrices as shown in Eq. (10). $\alpha$ and $\beta$ are proportionality constants can be solved using Eqs. $(6,7,8) . \omega_{\mathrm{i}}$ and $\omega_{\mathrm{j}}$ are taken as first and second mode frequencies.For practical purposes, the elasticity modulus of the infill wall can be taken as $500 \mathrm{f}_{\text {ckd }} \cdot \mathrm{f}_{\text {ckd }}$ is characteristic shear strength which is taken about $2000 \mathrm{kN} / \mathrm{m}^{2}$ [17]. Kanit and Donduren modeled masonry walls with similar geometrical properties using software and they compared numerical results with experimental results [18]. The general infill wall material characteristics of the building stock in Turkey are presented in Table 1 [19].

Table 1. Material Properties of Infill Walls

\begin{tabular}{|c|c|c|}
\hline Parameter & Lower Bound & Upper Bound \\
\hline \hline Mod.of elasticity $E(\mathrm{MPa})$ & 1500 & 5000 \\
\hline Comp. strength, $(\mathrm{MPa})$ & 1.90 & 3.2 \\
\hline Tensile strength, $(\mathrm{MPa})$ & 1.1 & 1.3 \\
\hline
\end{tabular}

The analyzed structural frame models are shown in Fig. (3). The location of infill walls are changed in every frame model therefore location of soft story is changed in every frame model. In addition to this the ratio between infill walls modulus of elasticity to frame modulus of elasticity is not constant as given in Table 2. There are four type of ratio (between wall and frame) has been used for analysis. The schematic view of equivalent strut model for infill walls is shown in Fig. (4). The section of the beam is $25 \times 50 \mathrm{~cm}$, the section of the column is $40 \times 40 \mathrm{~cm}$. The floor height is $3 \mathrm{~m}$ and the span is taken as $6 \mathrm{~m}$ as shown in Fig. (4).

Table 2. The Ratio Between infill Walls Material Mod. of Elasticity to Frame Material mod. of el.

\begin{tabular}{|c|c|c|c|c|}
\hline Model & Model 1 & Model 2 & Model 3 & Model 4 \\
\hline \hline $\mathbf{E}_{\mathrm{w}} / \mathbf{E}_{\mathrm{f}}$ & $1 / 16$ & $1 / 4$ & $1 / 2$ & $1 / 1$ \\
\hline
\end{tabular}

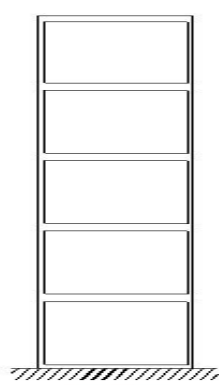

Model a

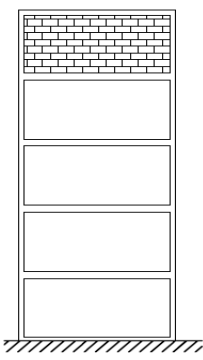

Model $\mathrm{f}$
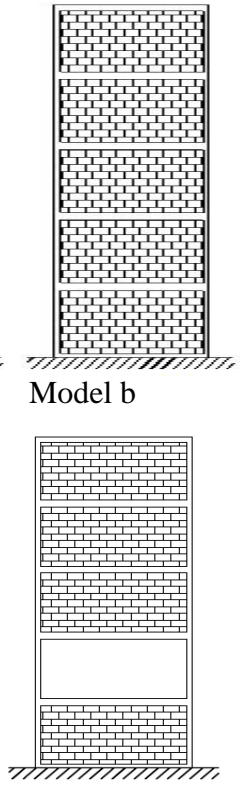

Model g

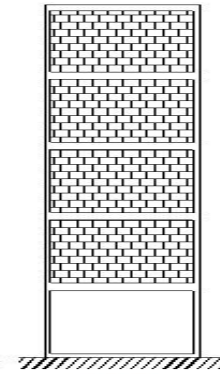

Model c

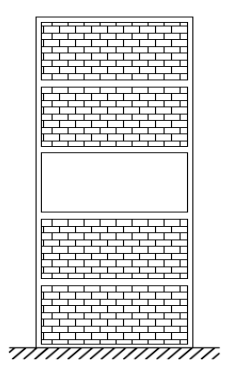

Model h
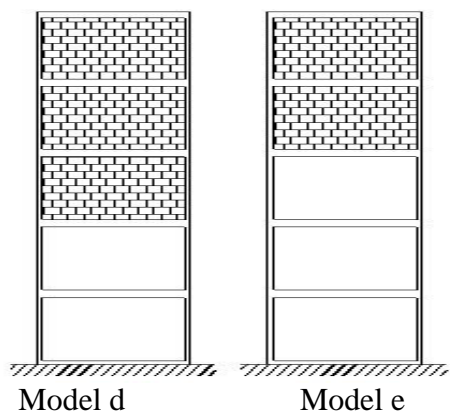

Model e

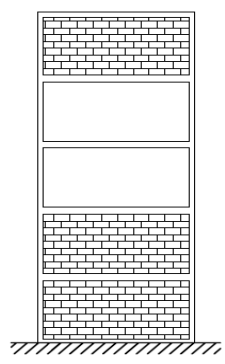

Model i

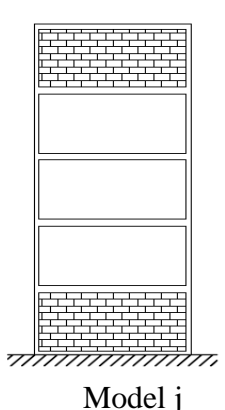

Fig. (3). Analyzed structural models (different configurations). 

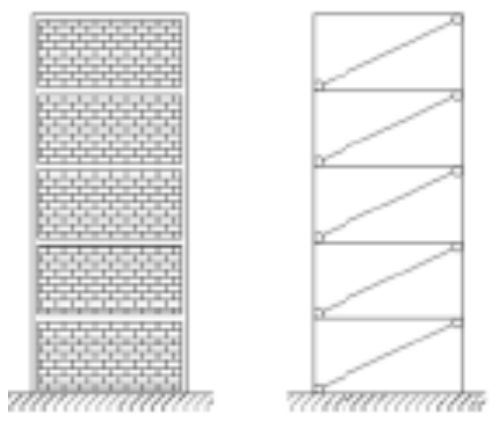

Fig. (4). Equivalent strut model for infill walls.

Ten different models are developed to investigate contribution of infill walls to the response of frame. The properties of analyzed models are given in Table 3. All models (a-j) are analyzed four times according to ratio of modulus of elasticity. All analyses are performed using by SAP2000 (FEM software) [20].

Table 3. Infill Wall Configuration Between Floors

\begin{tabular}{|l|l|l|l|}
\hline $\begin{array}{l}\text { Model } \\
\text { Name }\end{array}$ & Explanation & Model Name & Explanation \\
\hline \hline Model a & Bare frame & Model $\mathbf{f}$ & $\begin{array}{l}5^{\text {th }} \text { floors has infill } \\
\text { wall }\end{array}$ \\
\hline Model b & $\begin{array}{l}\text { All floors have } \\
\text { infill wall }\end{array}$ & Model $\mathbf{g}$ & $\begin{array}{l}1^{\text {st }}, 3^{\text {rd }}, 4^{\text {th }} \text { and } 5^{\text {th }} \\
\text { floors have infill } \\
\text { wall }\end{array}$ \\
\hline Model $\mathbf{c}$ & $\begin{array}{l}2^{\text {nd }}, 3^{\text {rd }}, 4^{\text {th }} \text { and } \\
5^{\text {th }} \text { floors have } \\
\text { infill wall }\end{array}$ & Model $\mathbf{h}$ & $\begin{array}{l}1^{\text {st }}, 2^{\text {nd }}, 4^{\text {th }} \text { and } 5^{\text {th }} \\
\text { floors have infill } \\
\text { wall }\end{array}$ \\
\hline Model d & $\begin{array}{l}3^{\text {rd }}, 4^{\text {th }} \text { and } 5^{\text {th }} \\
\text { floors have } \\
\text { infill wall }\end{array}$ & Model $\mathbf{i}$ & $\begin{array}{l}1^{\text {st }}, 2^{\text {nd }} \text { and } 5^{\text {th }} \text { floors } \\
\text { have infill wall }\end{array}$ \\
\hline Model e & $\begin{array}{l}4^{\text {th }} \text { and } 5^{\text {th }} \text { floors } \\
\text { have infill wall }\end{array}$ & Model $\mathbf{j}$ & $\begin{array}{l}1^{\text {st }}, \text { and } 5^{\text {th }} \text { floors } \\
\text { have infill wall }\end{array}$ \\
\hline
\end{tabular}

All models are analyzed using by El Centro earthquake record. Fig. (5) shows El Centro earthquake N-S ground acceleration data. El Centro earthquake was in May 1940 in Imperial Valley (USA) and the Richter magnitude of the earthquake was recorded as 7.1. The epicenter of the earthquake was $70 \mathrm{~km}$ from the ground and max acceleration was $0,341 \mathrm{~m} / \mathrm{s}^{2}$.

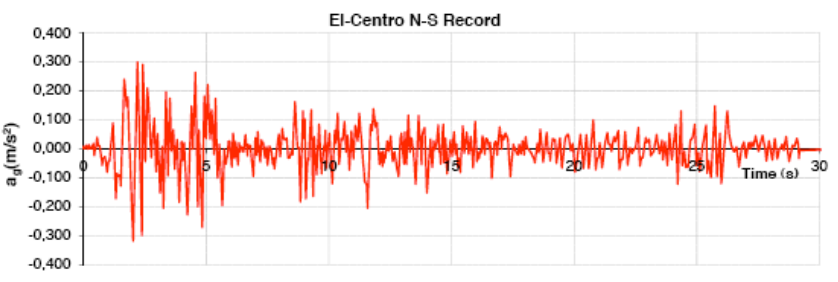

Fig. (5). The N-S component of El Centro earthquake (1940).

The natural vibration periods (three modes) of Model 1 is given in Table 4 . The ratio of modulus of elasticity is $1 / 16$ as shown in Table $\mathbf{3}$.

The natural vibration periods of Model 2 is given in Table 5. The ratio of modulus of elasticity is $1 / 4$ as shown in Table 3 .

The natural vibration periods of Model 3 is given in Table 6. The ratio of modulus of elasticity is $1 / 2$ as shown in Table 3.

The natural vibration periods of Model 4 is given in Table 7. The ratio of modulus of elasticity is $1 / 2$ as shown in Table 3.

The maximum displacement response for first ratio (Model 1) is given in Fig. (6). As shown in the figure, the maximum displacement is calculated for Model 1a (bare frame).

The maximum displacement response for second ratio (Model 2) is given in Fig. (7). As shown in the figure, the max. interstorey drift is calculated between Model $2 \mathrm{~h}$ and Model 2d.

The displacement results of analyzed models are given in Figs. (6-9) based on modulus of elasticity ratio (Table 3). As

Table 4. The Natural Vibration Periods of Model 1

\begin{tabular}{|c|c|c|c|c|c|c|c|c|c|c|}
\hline Mode & Model1a & Model1b & Model1c & Model1d & Model1e & Model1f & Model1g & Model1h & Model1ı & Model1j \\
\hline \hline 1 & 0,6526 & 0,374 & 0,4299 & 0,5348 & 0,6067 & 0,6418 & 0,4628 & 0,4364 & 0,483 & 0,582 \\
\hline 2 & 0,2037 & 0,123 & 0,138 & 0,139 & 0,1549 & 0,1854 & 0,1282 & 0,1307 & 0,152 & 0,165 \\
\hline 3 & 0,1116 & 0,073 & 0,0774 & 0,0839 & 0,0897 & 0,0966 & 0,0756 & 0,0836 & 0,087 & 0,088 \\
\hline
\end{tabular}

Table 5. The natural vibration periods of Model 2

\begin{tabular}{|c|c|c|c|c|c|c|c|c|c|c|}
\hline Mode & Model2a & Model2b & Model2c & Model2d & Model2e & Model2f & Model2g & Model2h & Model2i & Model2j \\
\hline \hline 1 & 0,6526 & 0,2436 & 0,3445 & 0,4958 & 0,5912 & 0,637 & 0,3676 & 0,3342 & 0,411 & 0,542 \\
\hline 2 & 0,2036 & 0,0801 & 0,1026 & 0,1033 & 0,1388 & 0,179 & 0,0872 & 0,0890 & 0,113 & 0,144 \\
\hline 3 & 0,1164 & 0,0467 & 0,0519 & 0,0725 & 0,0725 & 0,091 & 0,0527 & 0,0615 & 0,074 & 0,074 \\
\hline
\end{tabular}


Table 6. The Natural Vibration Periods of Model 3

\begin{tabular}{|c|c|c|c|c|c|c|c|c|c|c|}
\hline Mode & Model3a & Model3b & Model3c & Model3d & Model3e & Model3f & Model3g & Model3h & Model3i & Model3j \\
\hline \hline 1 & 0,6526 & 0,2021 & 0,3228 & 0,486 & 0,5875 & 0,636 & 0,3393 & 0,3057 & 0,393 & 0,530 \\
\hline 2 & 0,2036 & 0,0649 & 0,0906 & 0,0939 & 0,1355 & 0,178 & 0,0746 & 0,0728 & 0,099 & 0,139 \\
\hline 3 & 0,1164 & 0,0369 & 0,0422 & 0,0672 & 0,0693 & 0,090 & 0,0428 & 0,5346 & 0,067 & 0,071 \\
\hline
\end{tabular}

Table 7. The Natural Vibration Periods of Model 3

\begin{tabular}{|c|c|c|c|c|c|c|c|c|c|c|}
\hline Mode & Model4a & Model4b & Model4c & Model4d & Model4e & Model4f & Model4g & Model4h & Model4i & Model4j \\
\hline \hline 1 & 0,6526 & 0,1758 & 0,3106 & 0,4814 & 0,5854 & 0,636 & 0,322 & 0,289 & 0,383 & 0,524 \\
\hline 2 & 0,2036 & 0,0544 & 0,0827 & 0,0894 & 0,1338 & 0,177 & 0,066 & 0,06 & 0,092 & 0,136 \\
\hline 3 & 0,1116 & 0,0302 & 0,0356 & 0,0633 & 0,0681 & 0,090 & 0,034 & 0,047 & 0,059 & 0,069 \\
\hline
\end{tabular}

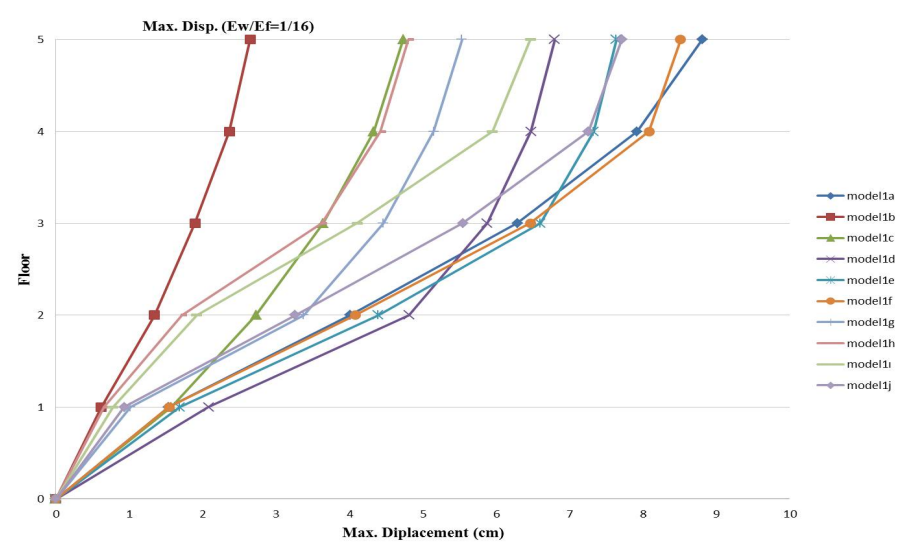

Fig. (6). Maximum displacement of Model 1.

shown in Fig. (6), the displacement of Model a (bare frame structure) gives the largest displacement compared with the other models with infill. Model $b$ gives the smallest displacement compared with other infill wall configurations. This result means infill walls increases lateral stiffness of the structure which leads decrease in lateral displacement of frame. In addition to this, frame can absorb more energy and if the infill is configured in regular mode. The interstorey displacement of floors without infill walls are much more than infilled frame. If all structural configurations are compared, Model 4 gives minimum displacement compared with other models have smaller modulus of elasticity. This result means increasing modulus of elasticity leads larger structural stiffness and less displacement response. Infill walls give additional lateral stiffness to the frame. If infill wall does not exist in any floor, this floor becomes soft story.

The base shear results of Model 1 analysis is given in Fig. (10). As shown in the figure Model 1d and Model $1 \mathrm{~g}$ gives the largest base shear force for Model 1.

\section{CONCLUSIONS}

In many applications, architectural considerations result in a taller first story, which causes a soft-story formation due to sudden change in the stiffness between following stories. If infill walls are not exist in any floor level means that floor is under risk of soft story collapse. The presence of a soft story results in a localized excessive drift that causes heavy damage or collapse of the story during a severe earthquake. In this paper, a detailed parametric study of the influence of

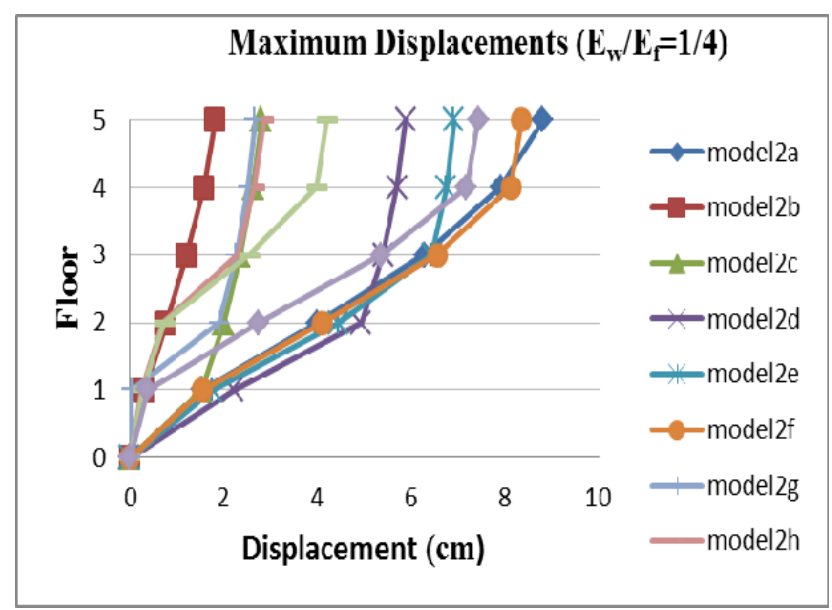

Fig. (7). Maximum displacement of Model 2. 
masonry infill on the behavior of frames subjected to earthquake forces using the finite element method for the analysis has shown the following consequences:

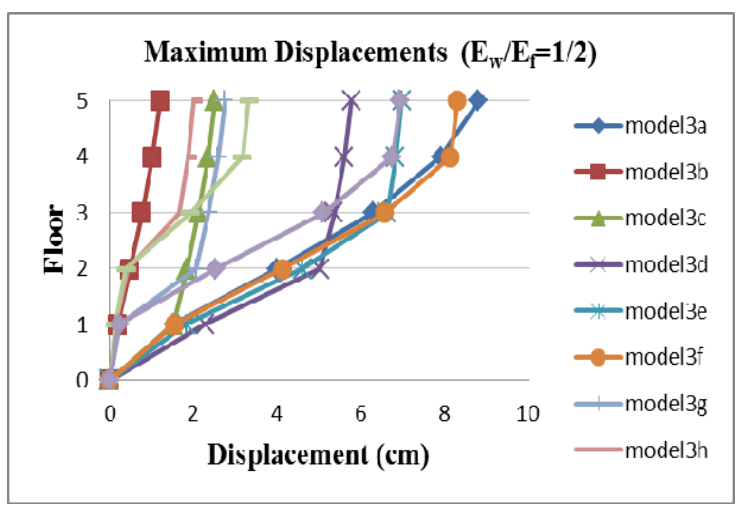

Fig. (8). Maximum displacement of Model 3

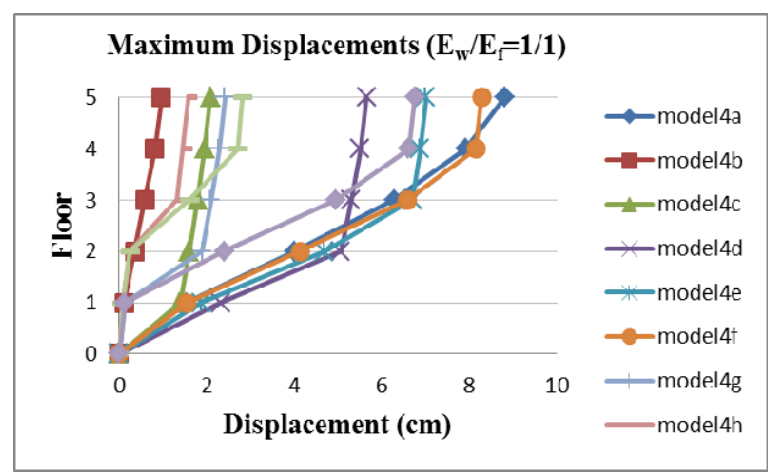

Fig. (9). Maximum displacement of Model 4.

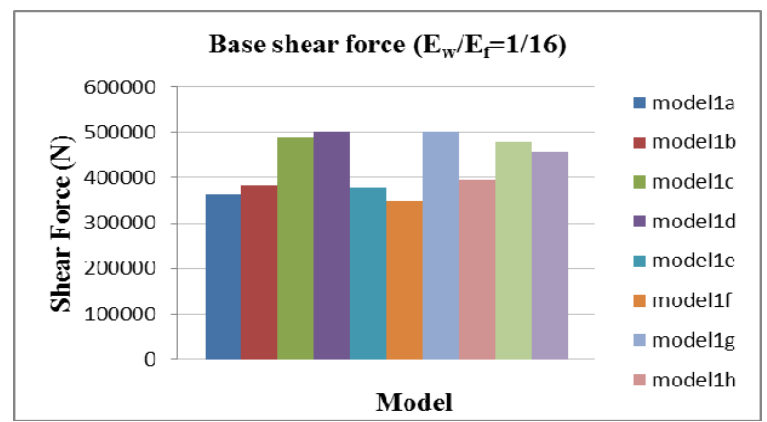

Fig. (10). Base shear of Model 1.

- The infill walls in multistory buildings have a considerable contribution to the stiffness and lateral resistance of frame. However those infills should be distributed in regular manner in the frame structure. In this case, infill walls decrease period of the structure and story displacements decrease. Otherwise (irregular distributed) infilled frame becomes much more rigid than bare frame which leads soft story collapse.

- The existence of infills walls causes, less shear forces on the frame columns. However, in the case of infilled frame with a soft ground story, the shear forces acting on columns are considerably higher than bare frame shear forces.

- The material quality of the infill frame (based on ratio between infill wall material and frame material modulus of elasticity) directly affect seismic response of the frame. Because modulus of elasticity of infill wall frame is directly proportional to the stiffness of the frame.

As a result of this study, the distribution of infill walls is very important for formation of soft story effect caused by earthquake. In order to prevent soft story collapse, the interstory drifts should be controlled and limited changing by stiffness of columns.

\section{CONFLICT OF INTEREST}

None declared.

\section{ACKNOWLEDGEMENT}

None declared.

\section{REFERENCES}

[1] H. S. Lee, and S. W. Woo, "Effect of masonry infills on seismic performance of A 3 storey RC frame with non-seismic detailing", Earthquake Eng. Struct. Dyn., vol. 31, pp. 353-378, 2002.

[2] M. Fardis, N. Bousias, G. Franchioni, and B. Panagiotakos, "Seismic response and design of RC structures with plan-eccentric masonry infills", Earthquake Eng. Struct. Dyn., vol. 28, pp.173-191, 1999

[3] A. Saneinnejad, and B. Hobbs, "Inelastic design of infilled frames", J. Struct. Eng., vol.121, pp. 634-650, 1995.

[4] A. Rutenberg, G. Shoet, and M. Eisenberger, "Inelastic seismic response of code designed asymmetric structures", Publ. Fac. Pub. 303, Faculty of Civil Engineering. Technion-Israel Institute of Technology, Haifa, 1989.

[5] M. Puglisi, M. Uzcategui, and J. Florez-Lopez, "Modeling of masonry of infilled frames, part I: the plastic concentrator", Eng. Struct. vol. 31, pp.113-118, 2009.

[6] M. Puglisi, M. Uzcategui, and J. Florez-Lopez, "Modeling of masonry of infilled frames, part II: cracking and damage", Eng. Struct., vol. 31, no. 1, pp.119-124, 2009.

[7] K. Meguro, and H. S. Tagel-Din, "Applied element method used for large displacement structural analysis", J. Nat. Disasters Sci., vol. 24, no. 1, pp. 25-34, 2002.

[8] H. A. Moghaddam, and P. J. Dowling, "The State of the Art in Infilled Frames", ECEE research Report no. 87-2. London: Civil Engineering Department, Imperial College of Science and Technology, 1987.

[9] F. J. Crisafulli, A. J. Carr, and R. Park. "Analytical modelling of infilled frames structures - A general review", Bull. N.Z. Soc. Earthquake Eng., vol.33, pp. 30-47, 2000.

[10] M. Tsai, and T. Huang, "Effect of interior brick-infill partitions on the progressive collapse potential of a RC building: linear static analysis results", Int J. Appl. Sci. Eng. Technol., vol. 6, no. 1, pp.17, 2010.

[11] A. Plumier, C. Doneux, L. Stoychev, and T. Demarco. "Advances in Steel Structures”, Z. Y. Shen, (Ed. Mitigation of soft storey failures of R.C, structures under earthquake by encased steel profiles, vol. II, Elsevier USA: 2005, pp.1195-1201.

[12] P. G. Asteris, D. J. Kakaletsis, C. Z. Chrysostomou, and E. E. Smyrou, "Failure modes of infilled frames", Elect. J. Struct. Eng., vol. 11, no. 1, pp.11-20, 2011.

[13] P. G. Asteris, "Lateral stiffness of brick masonry infilled plane frames", J. Struct. Eng., (ASCE), vol. 129, no. 8, pp. 1071-1079, 2003.

[14] P.G. Asteris, "Finite element micro-modeling of infilled frames", Elect. J. Struct. Eng., vol. 8, pp.1-11, 2008.

[15] P. G. Asteris, S. T. Antoniou, D. S. Sophianopoulos, and C. Z. Chrysostomou, "Mathematical macromodeling of infilled frames: state of the art", J. Struct. Eng., (ASCE), vol. 137, no. 12, pp. 15081517, 2011.

[16] A. Madan, and A. M. Reinhorn, "Modelling of masonary infill panels for structural analysis", J. Struct. Eng., (ASCE), vol. 123, pp. 1295-1302, 1997.

[17] D. Guney, and A. O. Kuruscu, "Optimization of the configuration of infill walls in order to increase seismic resistance of building structures", Int. J. Phys. Sci, vol. 6, no. 4, pp. 698-706, 2011. 
[18] R. Kanit, and M. S. Donduren, "Investigation of using ansys software in the determination of stress behaviors of masonry walls under out-of plane cycling load", Int. J. Phy. Sci., vol. 5, no. 2, pp. 97-108, 2010.

[19] G. Erol, E. Yuksel, H. Saruhan, G. Sagbas, P. T. Tuga, and H. F. Karadogan, "A complementary experimental work on brittle parti- tioning walls and strengthening by carbon fibers", Proceedings of the 13th World Conference on Earthquake Engineering, Vancouver, Canada, 2004

[20] CSI, SAP2000 V-14. Integrated finite element analysis and design of structures basic analysis reference manual; Computers and Structures Inc: Berkeley, California (USA) 2002.

(C) Guney and Aydin; Licensee Bentham Open.

This is an open access article licensed under the terms of the Creative Commons Attribution Non-Commercial License (http://creativecommons.org/licenses/by-nc/3.0/) which permits unrestricted, non-commercial use, distribution and reproduction in any medium, provided the work is properly cited. 